\title{
Perbandingan Faktor Risiko Gangguan Pemusatan Perhatian/hiperaktivitas di Daerah Pedesaan dan Perkotaan
}

\author{
Yosephine Maria Christina, Elisabeth S. Herini, IL. Gamayanti \\ Bagian Ilmu Kesehatan Anak Fakultas Kedokteran Universitas Gadjah Mada/RSUP. Dr. Sardjito, \\ Yogyakarta
}

\begin{abstract}
Latar belakang. Gangguan Pemusatan Perhatian/Hiperaktifitas (GPP/H) merupakan gangguan neurobehavioural yang menetap dengan gejala berupa ketidakmampuan memusatkan perhatian, hiperaktivitas, dan impulsivitas yang tidak sesuai dengan usia perkembangannya.

Tujuan. Mengetahui perbedaan angka prevalensi dan karakteristik faktor risiko yang menimbulkan GPP/H di pedesaan dan perkotaan.

Metode. Penelitian potong lintang untuk mengetahui prevalensi GPP/H dan dilanjutkan studi kasus kontrol untuk memperoleh faktor risiko yang memengaruhi terjadinya GPP/H di pedesaan dan perkotaan. Subyek penelitian terdiri dari anak SD kelas I - III.

Hasil. Prevalensi GPP/H di kecamatan Cangkringan 7,48\% dengan rasio prevalensi GPP/H antara laki-laki dan perempuan $6: 1$. Prevalensi di pedesaan $46 \%$ dan perkotaan $54 \%$. Hasil analisis bivariat menunjukkan perbedaan faktor risiko yang berpengaruh di pedesaan dan perkotaan adalah keluarga hiperaktif, komplikasi kehamilan, serta konsumsi makanan berpengawet dan berpewarna lebih tinggi di perkotaan. Sedangkan durasi interaksi dengan orang tua $<8$ jam, BBLR lebih berpengaruh di pedesaan. Hasil analisis multivariat memperoleh faktor risiko independent yang memengaruhi kejadian GPP/H adalah trauma kepala OR 15,97 (95\% CI 2,11-20,96); p=0,007, orang tua tunggal OR 182,47 (95\% CI 1,55-2,15); p=0,032, tidak ASI eksklusif OR 11,93 (95\% CI 1,84-78,93) p=0,01, dan penggunaan makanan berpengawet OR 0,05 (95\% CI 0,003-0,89); $\mathrm{p}=0,041$.

Kesimpulan. Prevalensi GPP/H di perkotaan lebih besar daripada di pedesaan. Faktor risiko yang berpengaruh pada masing-masing wilayah berbeda. Durasi interaksi dengan orang tua $<8$ jam, komplikasi kehamilan ibu, tidak ASI eksklusif merupakan faktor risiko kejadian GPP/H. Sari Pediatri 2013;15(4):225-31.
\end{abstract}

Kata kunci: gangguan pemusatan perhatian/hiperaktif, faktor risiko, pedesaan-perkotaan

\footnotetext{
Alamat korespondensi:

Dr. Yosephine Maria Christina, Sp.A. Bagian Ilmu Kesehatan Anak Fakultas Kedokteran Universitas Gadjah Mada/RSUP. Dr. Sardjito, Jalan Kesehatan No. 1 Sekip Yogyakarta 55284. Telp. (0274) 561616, Fax. (0274) 583745, E-mail: vina_christ@yahoo.com
}

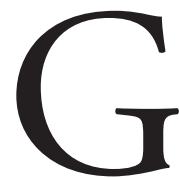

angguan pemusatan perhatian /hiperaktivitas $(\mathrm{GPP} / \mathrm{H})$ merupakan gangguan yang ditandai dengan manifestasi masalah hiperaktif, impulsif, dan pemusatan perhatian yang kurang. Manifestasi gejala GPP/H 
terjadi pada lebih dari dua situasi. Gangguan terkait dengan kesulitan dalam fungsi akademis, emosional, dan sosial. Gangguan terbanyak diderita oleh anak usia pra sekolah dan awal sekolah. ${ }^{1}$

Gangguan pemusatan perhatian/hiperaktifitas memiliki tiga gejala utama yang nampak dalam perilaku seorang anak, yaitu inatensi, hiperaktif, dan impulsif. Gangguan ditandai dengan ketidakmampuan anak untuk memusatkan perhatian pada sesuatu yang dihadapi sehingga rentang perhatian sangat singkat waktunya dibandingkan anak lain seusia. Pada umumnya disertai dengan gejala hiperaktif dan tingkah laku yang impulsif. Kelainan tersebut dapat mengganggu perkembangan anak dalam hal kognitif, perilaku, sosialisasi, maupun komunikasi. ${ }^{2}$

Angka prevalensi GPP/H sangat bervariasi, berkisar 2,2\% sampai dengan $17,8 \% .^{3}$ Anak laki-laki memiliki risiko menderita $\mathrm{GPP} / \mathrm{H}$ lebih tinggi dari anak perempuan dengan rasio laki-laki : perempuan $3: 1 .{ }^{4}$ Kriteria diagnosis GPP/H ditegakkan berdasarkan diagnostic and statisttical manual of mental disorders (DSM IV). Gejala yang dominan terjadi pada GPP/H adalah gangguan inatensi atau hiperaktif-impulsif, atau kombinasi gangguan inatensi-hiperaktif-impulsif.

Penyebab GPP/H secara pasti belum diketahui, tetapi beberapa faktor diduga dapat mencetuskan timbulnya gangguan tersebut, yaitu faktor genetik, laki-laki, prematuritas, ibu merokok saat hamil, faktor psikososial seperti pendapatan keluarga rendah, disfungsi keluarga, dan bermukim di daerah perkotaan. ${ }^{5}$ Dari segi faktor neurologik, insiden hiperaktif yang lebih tinggi didapatkan pada bayi yang lahir dengan masalah prenatal, seperti lamanya proses persalinan, distres fetal, persalinan dengan cara ekstraksi forsep, toksemia gravidarum atau eklampsia dibandingkan dengan kehamilan, dan persalinan normal. Di samping itu, faktor seperti bayi lahir dengan berat badan rendah, ibu terlalu muda, ibu merokok dan minum alkohol juga meninggikan insiden hiperaktif dan menyebabkan terjadinya perkembangan otak melambat. Beberapa zat dalam makanan seperti salisilat dan bahanbahan pengawet ditengarai memiliki potensi untuk membentuk perilaku hiperaktif pada anak. Di samping itu, peningkatan kadar timah dalam serum darah anak, ibu merokok dan mengkonsumsi alkohol, terkena sinar $\mathrm{X}$ pada saat hamil juga dapat melahirkan calon anak hiperaktif.

Secara garis besar jumlah kasus GPP/H lebih banyak teridentifikasi di daerah perkotaan. Faktor risiko yang dicurigai dapat meningkatkan kejadian GPP/H secara sosiodemografik lebih banyak terdistribusi di daerah perkotaan seperti paparan terhadap televisi dan video game, ibu merokok atau mengkonsumsi alkohol saat hamil, interaksi orang tua dengan anak kurang, dan konsumsi makanan berpengawet. Namun, perlu kita pertimbangkan bahwa terdapat faktor risiko yang tidak tergantung dari wilayah tempat tinggal anak, seperti jenis kelamin laki-laki dan keluarga dengan hiperaktivitas maka seharusnya di daerah pedesaanpun terdapat risiko terjadinya GPP/H. Oleh karena itu, perlu dilakukan penelitian tentang prevalensi dan perbandingan faktor risiko GPP/H di daerah pedesaan dan perkotaan. Dalam hal ini peneliti mengambil subyek di Kecamatan Cangkringan Kabupaten Sleman propinsi Daerah Istimewa Yogyakarta.

\section{Metode}

Penelitian rancangan potong lintang untuk mengetahui faktor risiko GPP/H pada anak usia sekolah kelas I - III di pedesaan dan perkotaan di Kecamatan Cangkringan, Kabupaten Sleman. Sekolah dasar dipilih secara cluster sampling dari 20 sekolah dasar yang tersebar di kecamatan Cangkringan. Didapatkan 10 sekolah dasar (5 sekolah dasar perkotaan dan 5 sekolah dasar pedesaan) sebagai berikut SD Gondang, SD Watuadeg, SD Cancangan, SD Muh. Kregan, SD Kiyaran 1, SD Gungan, SD Kuwang, SD Cangkringan 1, SD Cangkringan 2, SD Bronggang Baru. Kriteria inklusi apabila orang tua setuju mengikuti penelitian dengan menandatangani informed consent. Kriteria eksklusi meliputi anak yang tidak hadir saat dilakukan pemeriksaan, memiliki gangguan perkembangan, skizofrenia, gangguan psikotik lain atau gangguan mental lain. Perhitungan subyek jumlah subyek minimal 21 anak setiap kelompok.

Peneliti dibantu oleh asisten peneliti yang kompeten dalam bidangnya. Penelitian diawali dengan mengadakan pertemuan dengan guru dan orang tua untuk memberi penjelasan mengenai latar belakang dan tujuan penelitian, kemudian dibagikan informed consent untuk meminta persetujuan ikut serta dalam penelitian dengan sukarela, serta menjelaskan prosedur penggunaan abbreviated conners teacher rating scale (ACTRS) untuk skrining GPP/H tahap awal. Berdasarkan hasil ACTRS didapatkan siswa-siswi yang memiliki kecenderungan men- 
derita GPP/H. Kemudian dilakukan pemeriksaan berdasarkan DSM IV untuk menegakkan diagnosis GPP/H. Setelah pemeriksaan DSM IV didapatkan siswa yang menderita GPP/H. Kemudian orang tua siswa yang menderita GPP/H ini diminta kesediaannya untuk mengisi kuesioner yang berisi pertanyaan mengenai berbagai faktor risiko yang diduga memengaruhi timbulnya GPP/H. Kuesioner dikumpulkan kembali dan dilakukan analisis data berdasarkan data yang diperoleh.

Analisis data hasil penelitian akan dilakukan melalui 3 tahap, yaitu 1) deskripsi variabel penelitian, 2) analisis bivariat dengan uji kai kwadrat (chi-square), dan 3) analisis multivariat dengan uji regresi logistik untuk mengetahui hubungan antar variabel independen dengan variabel dependen pada waktu yang bersamaan.

\section{Hasil}

Penelitian melibatkan 628 anak kelas 1 - III sekolah dasar di kecamatan Cangkringan kabupaten Sleman. Karena jumlah anak di setiap sekolah dasar tidak sama, penelitian ini diwakili oleh 10 sekolah dasar, yaitu 9 sekolah dasar negeri dan satu sekolah dasar swasta.

Subyek yang diteliti dilakukan penjaringan kasus GPP/H dengan instrumen ACTRS (cut off point 13) oleh guru kelas dan orang tua anak masing-masing. Penggunaan alat ukur ini diharapkan guru kelas yang sebelumnya sudah mendapatkan pengarahan mengenai GPP/H dapat mengenal muridnya dan dapat menjaring anak yang dicurigai mengalami $\mathrm{GPP} / \mathrm{H}$. Hasil penjaringan oleh guru terhadap 628 anak (331 laki-laki dan 297 perempuan), didapatkan 121 anak yang dicurigai GPP/H.

Tabel 1. Distribusi jumlah anak yang masuk dalam populasi penelitian

\begin{tabular}{lccccccccc}
\hline \multirow{2}{*}{ Kelas } & \multicolumn{3}{c}{ Jumlah subyek } & \multicolumn{3}{c}{ Skor ACTRS $\geq 13$} & \multicolumn{3}{c}{ GPP/H sesuai DSM IV } \\
\cline { 2 - 10 } & $\mathrm{L}$ & $\mathrm{P}$ & total & $\mathrm{L}$ & $\mathrm{P}$ & total & $\mathrm{L}$ & $\mathrm{P}$ & total \\
\hline 1 & 141 & 81 & 222 & 34 & 11 & 45 & 20 & 5 & 25 \\
2 & 94 & 94 & 188 & 19 & 15 & 34 & 10 & 1 & 11 \\
3 & 96 & 122 & 218 & 31 & 4 & 35 & 13 & 2 & 15 \\
\hline Total & 331 & 297 & 628 & 84 & 30 & 114 & 43 & 8 & 51 \\
\hline
\end{tabular}

Tabel 2. Analisis bivariat faktor risiko GPP/H di pedesaan

\begin{tabular}{lccc}
\hline Variabel, $\mathrm{n}(\%)$ & $\begin{array}{c}\mathrm{GPP} / \mathrm{H} \\
(\mathrm{n}=20)\end{array}$ & $\begin{array}{c}\text { Bukan GPP/H } \\
(\mathrm{n}=20)\end{array}$ & $\mathrm{p}$ \\
\hline Keluarga hiperaktif & $12(60)$ & $3(15)$ & $0,003^{*}$ \\
Keluarga antisosial & $10(50)$ & $1(5)$ & $0,047^{*}$ \\
Orang tua tunggal & $6(30)$ & $1(5)$ & 0,091 \\
Durasi interaksi dengan orang tua $<8$ jam & $13(65)$ & $3(15)$ & $0,001^{*}$ \\
Komplikasi kehamilan & $9(45)$ & $3(15)$ & $0,029^{*}$ \\
Ibu merokok & $2(10)$ & 0 & - \\
Ibu minum alkohol & 0 & 0 & - \\
Prematuritas & $1(5)$ & $1(5)$ & 1,000 \\
BBLR & $5(25)$ & $2(10)$ & $0,047^{*}$ \\
Asfiksia & $4(20)$ & 0 & 0,106 \\
ASI eksklusif & $14(70)$ & $6(30)$ & $0,011^{*}$ \\
Gizi kurang & $4(20)$ & $1(5)$ & 0,342 \\
Trauma kepala & $7(35)$ & $3(15)$ & $0,008^{*}$ \\
Keracunan & 0 & 0 & - \\
Usia awal terpapar televisi $<2$ tahun & $15(75)$ & $6(30)$ & $0,004^{*}$ \\
Durasi terpapar televisi $>5$ jam & $5(25)$ & $2(10)$ & 0,470 \\
Konsumsi makanan berpengawet & $16(80)$ & $17(85)$ & 1,000 \\
Konsumsi makanan berpewarna & $17(85)$ & $15(75)$ & 0,695 \\
\hline
\end{tabular}


Anak yang diperiksa adalah anak yang memiliki nilai ACTRS $\geq 13$ (skor dari guru dan orang tua) dan hadir saat dilakukan pemeriksaan klinis, yaitu 114 anak yang terdiri dari 84 laki-laki dan 30 perempuan (Tabel 1). Pemeriksaan dilakukan terhadap semua anak yang hadir saat dilaksanakan pemeriksaan klinis yang masuk dalam populasi penelitian dan diperiksa pada waktu yang tidak sama. Pemeriksaan dilakukan terhadap semua anak yang hadir dengan melakukan pengamatan perilaku saat pemeriksaan dan wawancara terstruktur sesuai dengan kriteria diagnostik DSM IV.

Anak yang telah terdiagnosis GPP/H dengan DSM IV (51 anak) diperiksa tingkat kecerdasannya dengan alat ukur Wechsler Intelligence Scale for Children (WISC) oleh tim psikolog dari klinik Tumbuh Kembang Anak RSUP Dr. Sardjito. Empatpuluh tiga anak, terdiri dari 37 (86\%) anak laki-laki dan 6 (14\%) anak perempuan terdiagnosis GPP/H. Selanjutnya, dilakukan wawancara penggalian faktor risiko GPP/H kepada orang tua masing-masing. Prevalensi GPP/H pada anak usia 6-10 tahun di kecamatan Cangkringan Kabupaten Sleman 7,48\%, sedangkan prevalensi di daerah pedesaan $46 \%$ dan daerah perkotaan di kecamatan Cangkringan $54 \%$. Hasil penelitian ini sesuai dengan beberapa penelitian epidemiologi yang menunjukkan prevalensi pada komunitas anak usia sekolah berkisar 4\%-12\%. ${ }^{6}$ Prevalensi GPP/H pada anak laki-laki di Kecamatan
Cangkringan, Kabupaten Sleman 11,2\%, sedangkan anak perempuan $2 \%$. Sehingga rasio prevalensi GPP/H antara anak laki-laki dan perempuan adalah 6:1. Berdasarkan data pada Tabel 2 dan 3 didapatkan faktor keluarga dengan hiperaktif dan antisosial merupakan faktor risiko terjadinya GPP/H pada masa kanak baik di daerah pedesaan dan perkotaan dengan $\mathrm{p}<0,05$.

Komplikasi kehamilan dan penggunan ASI eksklusif merupakan faktor awal kehidupan yang memengaruhi kejadian risiko terjadinya GPP/H ( $\mathrm{p}<0,05)$. Riwayat trauma kepala, konsumsi makanan berpengawet dan berpewarna merupakan faktor lingkungan yang dapat meningkatkan risiko kejadian GPP/H.

Penelitian ini mendapatkan bahwa keluarga dengan hiperaktif, antisosial, orang tua tunggal, durasi interaksi dengan orang tua $<8$ jam, komplikasi kehamilan, asfiksia, tidak ASI eksklusif, trauma kepala, usia awal terpapar TV, durasi terpapar TV, dan konsumsi makanan dengan pengawet merupakan faktor risiko yang berpengaruh terhadap terjadinya GPP/H (Tabel 4).

Konsumsi makanan berpengawet dan berperwarna merupakan faktor risiko yang berpengaruh terhadap kejadian GPP/H di perkotaan. Hal tersebut disebabkan anak di pedesaan sedikit yang mendapatkan uang saku untuk membeli jajanan, sedangkan di perkotaan anak cenderung mendapatkan uang saku sehingga mereka

Tabel 3. Analisis bivariat faktor risiko GPP/H di perkotaan

\begin{tabular}{lccc}
\hline Variabel, $\mathrm{n}(\%)$ & $\begin{array}{c}\mathrm{GPP} / \mathrm{H} \\
(\mathrm{n}=23)\end{array}$ & $\begin{array}{c}\text { Bukan GPP/H } \\
(\mathrm{n}=23)\end{array}$ & $\mathrm{p}$ \\
\hline Keluarga hiperaktif (\%) & $5(22)$ & $2(8)$ & $0,049^{*}$ \\
Keluarga antisosial (\%) & $8(34)$ & $4(17)$ & $0,004^{*}$ \\
Orang tua tunggal (\%) & $3(13)$ & 0 & 0,233 \\
Durasi interaksi dengan orang tua $<8$ jam (\%) & $10(43)$ & $6(26)$ & 0,216 \\
Komplikasi kehamilan (\%) & $12(52)$ & $3(13)$ & $0,005^{*}$ \\
Ibu merokok (\%) & 0 & 0 & - \\
Ibu minum alkohol (\%) & 0 & 0 & - \\
Prematuritas (\%) & $4(17)$ & $1(4)$ & 0,346 \\
BBLR (\%) & $4(17)$ & $2(8)$ & 0,665 \\
Asfiksia (\%) & $10(43)$ & $6(26)$ & 0,216 \\
ASI eksklusif (\%) & $14(60)$ & $6(26)$ & $0,017^{*}$ \\
Gizi kurang (\%) & $5(22)$ & $2(8)$ & 0,414 \\
Trauma kepala (\%) & $12(52)$ & $1(4)$ & $0,001^{*}$ \\
Keracunan (\%) & $1(4)$ & 0 & 1,000 \\
Usia awal terpapar televisi <2 tahun (\%) & $8(34)$ & $5(22)$ & 0,326 \\
Durasi terpapar televisi $>5$ jam (\%) & $4(17)$ & 0 & 0,109 \\
Konsumsi makanan berpengawet (\%) & $12(52)$ & $10(43)$ & $0,001^{*}$ \\
Konsumsi makanan berpewarna (\%) & $14(60)$ & $9(40)$ & $0,001^{*}$ \\
\hline
\end{tabular}


Yosephine Maria Christina dkk: Perbandingan faktor risiko gangguan pemusatan perhatian/hiperaktivitas

Tabel 4. Analisis bivariat faktor risiko GPP/H di pedesaan dan perkotaan

\begin{tabular}{lccc}
\hline Variabel, $\mathrm{n}(\%)$ & $\begin{array}{c}\mathrm{GPP} / \mathrm{H} \\
(\mathrm{n}=43)\end{array}$ & $\begin{array}{c}\text { Bukan GPP/H } \\
(\mathrm{n}=43)\end{array}$ & $\mathrm{p}$ \\
\hline Keluarga hiperaktif & $17(40)$ & $5(11)$ & $0,003^{*}$ \\
Keluarga antisosial & $18(42)$ & $8(18)$ & $0,09^{*}$ \\
Orang tua tunggal & $9(20)$ & $1(2)$ & $0,007^{*}$ \\
Durasi interaksi dengan orang tua $<8$ jam & $23(53)$ & $9(21)$ & $0,003^{*}$ \\
Komplikasi kehamilan & $21(49)$ & $6(14)$ & $0,001^{*}$ \\
Ibu merokok & $2(4)$ & 0 & $0,494^{*}$ \\
Ibu minum alkohol & 0 & 0 & - \\
Prematuritas & $5(12)$ & $2(4)$ & 0,433 \\
BBLR & $9(20)$ & $4(8)$ & 0,132 \\
Asfiksia & $14(32)$ & $6(14)$ & $0,041^{*}$ \\
ASI eksklusif & $28(65)$ & $12(28)$ & $0,001^{*}$ \\
Gizi kurang & $9(20)$ & $3(7)$ & 0,062 \\
Trauma kepala & $19(44)$ & $4(8)$ & $0,001^{*}$ \\
Keracunan & $1(2)$ & 0 & 1,000 \\
Usia awal terpapar televisi $<2$ tahun & $23(53)$ & $11(25)$ & $0,008^{*}$ \\
Durasi terpapar televisi $>5$ jam & $9(20)$ & $2(4)$ & $0,024^{*}$ \\
Konsumsi makanan berpengawet & $28(65)$ & $27(62)$ & $0,001^{*}$ \\
Konsumsi makanan berpewarna & $31(72)$ & $24(55)$ & 0,058 \\
\hline
\end{tabular}

Tabel 5. Analisis multivariat faktor risiko GPP/H di pedesaan dan perkotaan

\begin{tabular}{lccccc}
\hline Variabel & $\beta$ & SE & OR & $95 \%$ IK & $p$ \\
\hline Trauma kepala & 2,77 & 1,003 & 15,97 & $2,11-20,96$ & $0,007^{*}$ \\
Orang tua tunggal & 5,21 & 2,43 & 182,47 & $1,55-2,15$ & $0,032^{*}$ \\
Tidak ASI eksklusif & 2,48 & 0,96 & 11,93 & $1,84-78,93$ & $0,01^{*}$ \\
\hline
\end{tabular}

lebih banyak membeli jajanan dan risiko terpapar makanan berpengawet dan berpewarna lebih tinggi.

Setelah dilakukan analisis multivariat, didapatkan bahwa komplikasi kehamilan pada ibu, durasi interaksi dengan orang tua dan penggunaan ASi eksklusif merupakan variabel bebas yang berhubungan bermakna terhadap terjadinya GPP/H pada anak sekolah dasar kelas I - III di Kecamatan Cangkringan (Tabel 5).

\section{Pembahasan}

Keluarga hiperaktif merupakan faktor risiko di daerah pedesaan dibandingkan di perkotaan karena kejadian GPP/H pada usia dewasa di pedesaan lebih banyak dibandingkan perkotaan. Secara tidak langsung, hal tersebut akan memengaruhi kejadian GPP/H pada anak. Durasi interaksi dengan orang tua $<8$ jam merupakan faktor risiko yang memengaruhi kejadian GPP/H di pedesaan. Orang tua di pedesaan Kecamatan Cangkringan cenderung bekerja full time sebagai buruh. Ketika mereka bekerja, anak akan diasuh oleh anggota keluarga yang lain atau tetangga. Sebagian besar anak tersebut menghabiskan waktu bermain dan melihat televisi dengan waktu yang tidak terbatas sehingga data ini mendukung bahwa faktor usia awal terpapar televisi $<2$ tahun sebagai faktor risiko penyebab GPP/H di pedesaan.

Kejadian BBLR di pedesaan memiliki nilai signifikan dibanding perkotaan. Kondisi BBLR dapat diakibatkan oleh berbagai faktor penyebab yang dimulai sejak awal kehamilan atau trimester akhir. Jika kondisi BBLR diakibatkan oleh gangguan kehamilan awal, risiko terjadi GPP/H lebih besar dibandingkan pada trimester akhir. Kami tidak memperoleh penyebab BBLR karena keterbatasan peneliti. Adanya riwayat trauma kepala sebelumnya akan meningkatkan risiko terjadinya GPP/H 15,975 kali lebih tinggi dibandingkan anak yang tidak mengalami trauma kepala sebelumnya. Sejalan dengan penelitian sebelumnya yang dilakukan oleh Keenan ${ }^{11}$ yang menyatakan bahwa kejadian trauma kepala pada 
usia kurang dari dua tahun akan meningkatkan risiko kejadian GPP/H. Kondisi trauma kepala maupun asfiksia akan menyebabkan hipoksia pada otak yang akan memengaruhi perkembangan otak.

Prevalensi GPP/H di kecamatan Cangkringan didominasi anak laki-laki, sesuai dengan hasil yang dikemukakan Polanczyk dkk ${ }^{6}$ bahwa prevalensi GPP/H antara anak laki-laki dan perempuan adalah 3:1 sampai dengan 10:1. ${ }^{7}$ Dugaan perbedaan prevalensi GPP/H anak laki-laki dan perempuan dapat terjadi karena anak perempuan lebih predominan inatensi. Sehingga lebih sedikit yang dilaporkan dan dirujuk untuk terapi karena kurang menyebabkan masalah di lingkungan keluarga dan sekolah.

Lange $\mathrm{dkk}^{7}$ dan Gau $\mathrm{dkk}^{8}$ mengemukakan bahwa GPP/H merupakan keadaan yang diturunkan. Hal tersebut diperkuat dengan adanya kondisi hiperaktif pada keluarga yang ditemukan pada anak dengan GPP/H. Selain pengaruh genetik keluarga, faktor lingkungan keluarga juga berpengaruh, seperti yang dikemukakan oleh Gau $\mathrm{dkk}^{8}$ bahwa anak yang mempunyai waktu interaksi yang terbatas dengan orang tua akan berisiko mengalami GPP/H. Kondisi trauma kepala maupun asfiksia akan menyebabkan hipoksia pada otak yang akan memengaruhi perkembangan otak.

Kami memperoleh beberapa faktor risiko yang berperan pada kejadian GPP/H. Daerah pedesaan dan perkotaan memiliki distribusi jenis faktor risiko yang berlainan. Faktor prenatal atau komplikasi kehamilan yang meliputi hiperemesis gravidarum, perdarahan pervaginam, dan hipertensi kehamilan merupakan komplikasi yang berkaitan dengan kejadian GPP/H baik di pedesaan maupun perkotaan. ${ }^{10}$ Kelahiran prematur dan bayi berat lahir rendah bukan merupakan faktor risiko terjadinya GPP/H. Hal tersebut sesuai dengan hasil penelitian yang dilakukan oleh Sauver $\mathrm{dkk}^{4}{ }^{4}$

Kejadian asfiksia pada bayi baru lahir merupakan salah satu risiko penyebab GPP/H. Willcutt ${ }^{10}$ mengemukakan bahwa kejadian GPP/H lebih banyak terjadi pada bayi dengan riwayat skor APGAR yang rendah. Kelemahan penelitian kami adalah data mengenai skor APGAR tidak dapat diperoleh karena pencatatan yang kurang memadai. Riwayat trauma kepala termasuk dalam faktor risiko yang berpengaruh pada kejadian GPP/H.

Pengaruh paparan televisi terhadap kejadian GPP/H seperti yang dikemukakan oleh Christakis dkk ${ }^{12} \mathrm{dan}$ Miller $\mathrm{dkk}^{13}$ merupakan faktor risiko timbulnya GPP/H. Penekanan adalah pada usia dan durasi saat terpapar dengan televisi. Usia paparan dengan televisi kurang dari 2 tahun dianggap memengaruhi terjadinya GPP/H pada usia sekitar 7 tahun.

Olech dan Jastrzebska ${ }^{14}$ menyatakan bahwa peggunaan air susu ibu (ASI) dengan durasi yang pendek berhubungan dengan kejadian GPP/H. Kedua peneliti tersebut membandingkan antara subyek yang mendapatkan ASI selama 6 bulan dengan subyek yang mendapatkan ASI kurang dari 6 bulan. Kami menemukan bahwa anak dengan GPP/H mempunyai riwayat tidak mendapatkan ASI eksklusif.

McCan $\mathrm{dkk}^{15}$ menyatakan bahwa penggunaan zat pengawet sodium benzoate meningkatkan kejadian GPP/H pada anak usia 8/9 tahun. Pada penelitian kami, data penggunaan zat pengawet diperoleh berdasarkan anamnesis. Peneliti memiliki keterbatasan untuk melakukan pemeriksaan secara obyektif terhadap zat pengawet yang dicurigai.

Trauma kepala sebelumnya akan meningkatkan risiko terjadinya GPP/H 16 kali lebih tinggi dibandingkan anak yang tidak mengalami trauma kepala sebelumnya. Trauma kepala ringan pada anak telah dikaitkan dengan kejadian gangguan psikiatri terutama perilaku hiperaktif. Tetapi pernyataan tersebut masih kontroversial sampai saat ini. ${ }^{11}$

\section{Kesimpulan}

Prevalensi GPP/H pada anak usia sekolah dasar kelas I-III di Kecamatan Cangkringan Kabupaten Sleman 7,48\% dengan rasio jenis kelamin laki-laki dibanding perempuan 6:1. Prevalensi kejadian GPP/H di daerah perkotaan lebih tinggi dibandingkan daerah pedesaan. Faktor risiko GPP/H yang terjadi di pedesaan dan perkotaan memiliki kesamaan, seperti keluarga hiperaktif dan antisosial, komplikasi kehamilan pada ibu, tidak ASI eksklusif, dan trauma kepala. Faktor risiko waktu interaksi dengan orang tua kurang, BBLR, usia awal terpapar televisi $<2$ tahun didapatkan di pedesaan. Faktor risiko terjadinya GPP/H pada anak usia sekolah di Kecamatan Cangkringan adalah riwayat trauma kepala, tidak mendapatkan ASI eksklusif, dan orang tua tunggal.

\section{Daftar pustaka}

1. National Institutes of Mental Health. Attention deficit hyperactivity disorder. Maryland: Department of Health 
And Human Services; 2000.

2. American Psychiatric Association. Diagnostic and statistical manual of mental disorders. Edisi ke-4. Washington DC; 1994.

3. Skounti M, Philalithis, Galanakis E. Variations ini prevalence of attention deficit hiperactivity disorder worldwide. Eur J Pediatr 2007;166:117-23.

4. Sauver JL, Barbaresi WJ, Katusic SK, Colligan RC, Weaver AL, Jacobsen SJ. Early life risk factors for attention-deficit/ hyperactivity disorder: a population-based cohort study. Mayo Clin Proc 2004;79:1124-31.

5. American Academy of Pediatrics Subcommittee on GPP/H Committee on Quality Improvement. Clinical practice guideline: treatment of the school-aged child with attention-deficit/hyperactivity disorder. Pediatrics 2001;108:1033-44.

6. Polanczyk G, de Lima MS, Horta BL, Biederman J, Rohde LA. The worldwide prevalence of GPP/H: a systematic review and metaregression analysis. Am J Psychiatry 2007;164:942-8.

7. Lange G, Sheerin D, Carr A. Family factors assosiated with attention deficit hyperactivity disorder and emotional disoerders in children. J Fam Pract 2005;27:76-96.

8. Gau SS. Parental and family factors for attention-deficit hyperactivity disorder in taiwanese children. Am J Psychiatry 2007;41:668-96.

9. Sasaluxnannon C, Kaewpornsawan T. Risk factor of birth weight below 2.500 grams and GPP/H in Thai children. J Med Assoc Thai 2005;88:1514-8.

10. Willcutt E. The etiology of GPP/H. London: Oxford University Press; 2007.

11. Keenan HT, Hall GC, Marshall SW. Early head injury and $\mathrm{GPP} / \mathrm{H}$ : retrospective cohort study. BMJ 2008;337:1-4.

12. Christakis DA, Zimmerman FJ, DiGiuseppe DL, McCarty CA. Early television exposure and subsequent attentional problems in children. Pediatrics 2004;113:708-13.

13. Miller CJ, Marks DJ. Television viewing and risk for attention problems ini preschool children. J Pediatr Psychol 2007;34:448-52.

14. Olech H, Jastrzebska J. The duration of breastfeeding and attention hyperactivity disorder. Ann Acad Med Bialos 2005;50:302-6.

15. McCAnn D, Barrett A, Cooper A. Food additives and hyperactive behaviour in 3-year-old and 9-yearold children in the community: a randomized, double-blinded, placebo-controlled trial. The Lancet 2007;370:1560-7. 